\title{
Learning Model Developing of Basic Technique for Three-Dimensional Table Tennis Punch Drive for Beginner Players
}

\author{
Samsuddin Siregar, Firmasnyah Dlis, Achmad Sofyan Hanif, James Tangkudung, \\ Nofimarlina Siregar
}

\begin{abstract}
This study aims to develop a learning model of three-dimensional table tennis-based basic drive punch techniques in beginner players, obtain information on the effectiveness of the three-dimensional basis-based learning drive technique models in improving basic skills of beginner player drive punch techniques. This study is research and development using the Borg and Gall (2007) model which consists of ten steps, namely (1) Research and information collection, (2) Planning, (3) Preliminary from of product, (4) Preliminary field testing, (5) Main product revision (6) Main field testing, (7) Operation product revision, (8) Operational field testing, (9) Revision product, (10) Dissemination and implementation. The sample in this study was students of the Physical Education and Recreation Education Study Program. The instruments used questionnaires, documentation, tests and assessment sheets. Then the effectiveness test is carried out using a before-after experimental design (one-group pre-test and post-test design). The research result is the compilation of a book on the basic three-dimensional table tennis drive learning technique for beginner players. This product was developed based on evaluation and advice from experts which included three table tennis learning experts, one media expert and two motor experts. The evaluation results of the experts stated that the model developed was suitable for use by novice players. Then the results of the small group trial stated that the product developed could be applied by students but still being improved and needed to be tested in large groups. The results of a large group trial stated that the product developed was able to be carried out well by students without repeated explanation. The results of the effectiveness test showed that drive learning by using a three-dimensional based learning model was significantly better than learning table tennis by using a conventional model to improve the basic technical skills of beginner player drives.
\end{abstract}

Keyword: Development, Drive, Learning Model, Table Tennis, Three-Dimensional.
Revised Manuscript Received on September 22, 2019.

Samsuddin Siregar, Postgraduate of Health and Recreation Physical Education from Universitas Negeri Medan, NorthSumatera, Indonesia. E-mail: sambatusundung@gmail.com

Firmasnyah Dlis, Professor of Physical Education, Postgraduate Program, Jakarta State University, Indonesia. E-mail firmansyahdlis.unj@gmail.com

Achmad Sofyan Hanif, Professor of Physical Education, Postgraduate Program, Jakarta State University, Indonesia. E-mail: sofyan_dean@yahoo.com

James Tangkudung, Professor of Physical Education, Postgraduate Program, Jakarta State University, Indonesia. E-mail: james24061952@gmail.com Program, Jakarta State University, Indonesia. E-mail: nofisiregar_fik96@yahoo.com
Nofimarlina Siregar, Lecture of Physical Education, Postgraduate

\section{INTRODUCTION}

Table tennis is a popular game in the world(1). It is not only talking about the popularity of table tennis in education but also talking about its learning material becauseit is taught in schools starts from the basic level up to the high level(2). Then at the university level which has a faculty of sports science studies, table tennis is a compulsory subject to be taught to the students (later be a sports teachers)(3)and at some universities, this kind of sport is as the elective sport. Through the course of table tennis sports, it is hoped that students have an understanding and skills in mastering various basic techniques, rules and how to play table tennis, so that it can be a support provision for students as ateacher candidates for physical and health education later on $(4,5)$.A Three-dimensional technology is a process to form an image from a model which is formed by animation software, the model contains geometry data, points of view, textures and lighting which is needed to make a complete picture (6). Three-Dimensions passes the Rendering process(7), which is a very important process and it has been used for various uses such as computer game programs, special effects on films and simulation programs (8). This three-dimensional technology can be implemented in table tennis in displaying the best driveto produce numbers. In university, to be a skilled person in playing table tennis must through the learning and training process(9). A good learning process is of course about the interaction process between teachers and students to achieve the learning goals, so they can change themselves and improve their abilities / skills in supporting and maximizing the performance. Teachers are the facilitators for students in acquiring the knowledge, skills and behavior changes by integrating existing computer applications into three-dimensional design. Teachers or physical education teachers need to create a learning environment which can stimulate and encourage a positive approach for achieving goals to enable players especially novice players to learn easily, has a personal progress, and still be interested in playing table tennis (10).Game-based teaching adapts tools and lessons, free expression of tactic skills rather than strict technical control, good communication,those are the main factors which effectively introduce playing programs, emphasize that the success key of novice player is to make them play table tennis since the first lesson, allthis can be converted into a three-dimensional application $(11,12)$. Unfix selection models so far is stiil using konvensional learning concept. 
Learning started from lecturer lecturing-students listening, lecturer modelling- students observing, the next is lecturer gives instruction to the students to imitate the action individually or groups. The used media is also so simple. The way of teaching like this make the table tennis drive learning is not optimal in gathering students active in learning process, it is not maximal to develop the students skills. Students learning outcomes are also still low which isas the impact of the learning process obtained by students during a table tennis lecturing with the lecturer. Then Nakashima, Nonomura, Liu \& Hayakawa conduct research, "Develop a robotic table tennis system to help backspin with the same measurement methods and ball movement models. Experimental results have been proven to verify the effectiveness of the proposed method. Because robot dynamics were not considered in this study, tracking errors caused failure to hit the ball'. This research develops a robot table tennis system to help the backspin ability with the same measurement methods and ball motion models. Experimental results have been proven to verify the effectiveness of the proposed method. But its weakness, Robot dynamics were not considered in this study. so an object tracking error occurs causing the player to fail to hit the ball.

Table tennis drive learning activities which are integrated in three dimensions with game values is an activity concept which is designed as a form of fun activity learning, joyful and educational in which there are elements of competition, targets, obstacles, rewards and cooperation. The process of table tennis drive learning activities is not only focus on physical activity priority, but also the values that must be obeyed and it is expected that these values are inherent in the students' personalities so that they can practice in their lives(13). Besides this developed model can increase the skills and develop the students' academic abilities in table tennis drive basic technique, by using three-Dimension technology, it is also can make the table tennis drive learning more efficient and effective. Therefore, the researcher wants to develop a learning model for table tennis drive blowing techniques based three-dimension for novice,then effectiveness test is done to gain the informations about the advantages of the model in increasing player understanding and drive blowing skills.

\section{Literature REVIEW}

Learning is an activity process that is arranged in such a way based on various aspects both concerning aspects of the concept(14), as well as formal juridical provisions that govern the implementation of education in general and specifically learning. Educators must be smart in designing the learning process in order to attract the attention of students to be interested in following the learning process. It is explained that the physical education of teachers or coaches need to create stimulation, encouraging learning environment and cultivate a positive approach to goal achievement in order to enable players and learn to be easy, experience personal progress(15), and remain interested in playing table tennis $(16,17)$. These are all major factors effectively introducing the Play and Stay tennis program(18), stresses which are rather than strict technical control, good communication, and good communication to get them playing table tennis from the very first lesson. To create a pleasant learning process condition, it depends on how educators create learning activities for their students with comprehensive scientific studies. The game is integrated in the table tennis learning process and becomes a means to an end namely increasing learning. As rough segmentation results and high spatial distortion rates, a sports video image segmentation method based on fuzzy clustering algorithm is proposed.

The illustration of drive technique model development bases three-dimension is started from the stage of modelling,coloring, lighting and arranging. Manufacturing model of three-dimension suites to the multimedia needs will be drawn with the focus on the framework, object movement angles. Coloring is real to the object. Model arranging, here the model that has been formed and already coloring is positioned into environment model or the position near to table tennis field. In this each stages will be done a testing sistematically and sequentially, if it is failed in the first stage then the second tested cannot be done..

\section{Methodology / Materials}

The approach which is used in this model development refers to Borg and Gall consists of 10 (ten) development stages, namely:

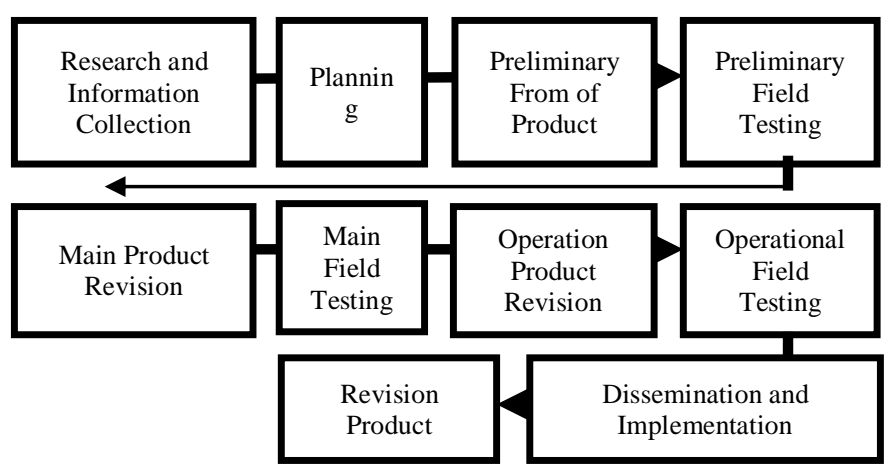

Figure 1. Stages Model Development(19)

\section{1) Preliminary Study}

Preliminary study activities are carried out by surveys, observations, interviews the table tennis lecturers and students who have already followedthe table tennis drive basic techniques lecturing to obtain information about the lecturing facilities and infrastructures. Then, the results of the observations and interviews were analyzed to be taken into consideration in the development of a three-dimensional table tennis drive learning model. Some of the focus points of preliminary studies are the goals of table tennis drive learning, competencies that must be achieved by students, learning resources used, media / tools used, models and methods used, barriers to student learning, descriptions of learning expected by students.

2) Planning 


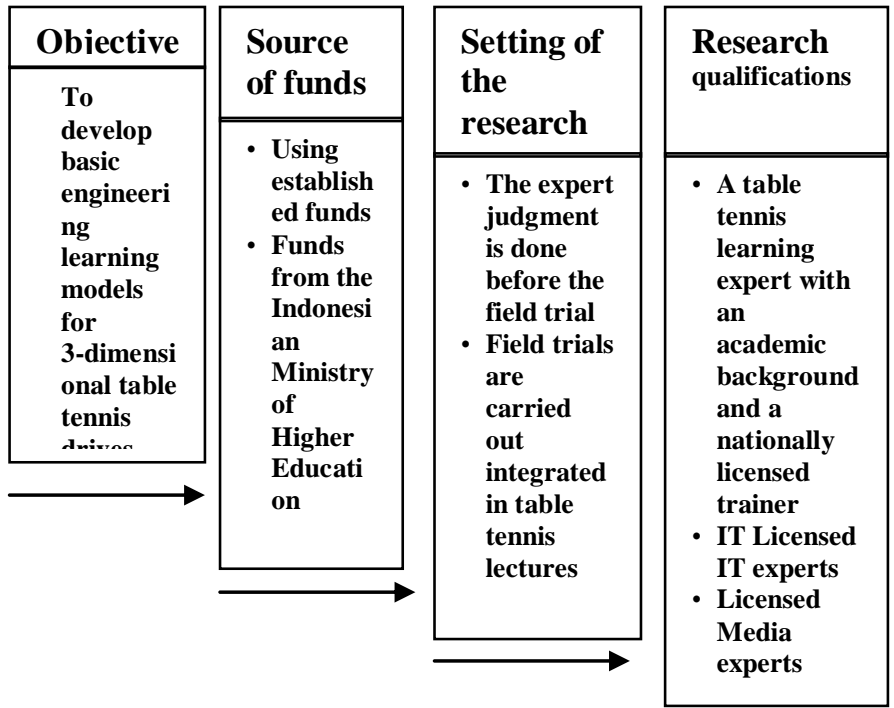

Figure 2. Planning Stage

\section{3) Developing preliminary of Product}

For the development of a basic three-dimensional table-based drive learning model, researchers collaborated with supervised lecturers in table tennis courses, learning media experts, technology information experts and table tennis learning experts. The goal is to get input in designing the basic technical learning model form table tennis drive. The planning and development steps which have been done are to formulate a development plans includes the equipment and mediaidentification to be used, determine the objectives to be achieved in arranging the lesson plan, learning implementation and table tennis drive basic technics learning evaluation. Then, the three-dimensional table tennis drive learning model is evaluated by experts as the expert judgment to find out the reliability and validity of the developed model to be examined later.

\section{4) Preliminary Field Testing}

At the preliminary field testing stage, 30 students in the Physical Health and Recreation Education Study Program are tested. Preliminary field testing is carried out in 5 meetings. The purpose of this phase is to get input, identify and refine the basic three-dimensional table-based drive learning model. The steps consist of an explanation about the product concept to students, provides an explanation about the usefulness of the model which developed for mastering the basic techniques of table tennis drive, asking students to practice the table tennis drive basic technique three-dimensional based. The next isasking lecturer to give a response or opinionabout the three-dimensional based learning model by filling out the questionnaire.

5) Main Product Revision

At this stage, the observations during the preliminary field testing process, a study between the researchers and experts have been doneto do the review and analysis of the design of table tennis drive basic technique three-dimensional based learning model. The aim is to correct the weaknesses, the shortcomings of the developing model to make it more perfect and feasible to continue to wider trials.

\section{6) Main Field Test}

The Main Field Testing was conducted after a small group scale trial. The target of large group scale trial was 90 students who had participated in table tennis subject. The target of large-scale trials is spreaded across 3 Universities, namely Universitas Negeri Medan, Sekolah Tinggi Olahraga Kesehatan Binaguna Medan and Universitas Pembangunan Masyarakat Indonesia Medan. The research was conductedfor one semester (February up to May 2018). The trial of the learing model development of table tennis drive three-dimensional based was carried out based on the learning planning program that had been designed before.

7) Operational Product Revision

The observation result during the process of main field testing, the researcher and the experts together doing the review and the analysisabout the design application of the table tennis drive basic technique three-dimensional based learning model. The aim is to improve the weaknesses, the shortcomings of the developing model to make it more perfect and feasible to continue to wider trials.

\section{8) Operation Field Testing}

Operation Field Testing was carried out after passing a small group scale trials and large group scale trials, which aim is to see whether the table tennis drive basic technique three-dimensional based learning model was able to provide a change in improving students' skills in tennis table drive basic technique. The Operation Field Testing technique is carried out by conducting experiments, comparing the learning outcomes before and after giving the table tennis drive basic technique three-dimensional based learning model with the design of "one group pretest-posttest design". The steps are carried out as follows.

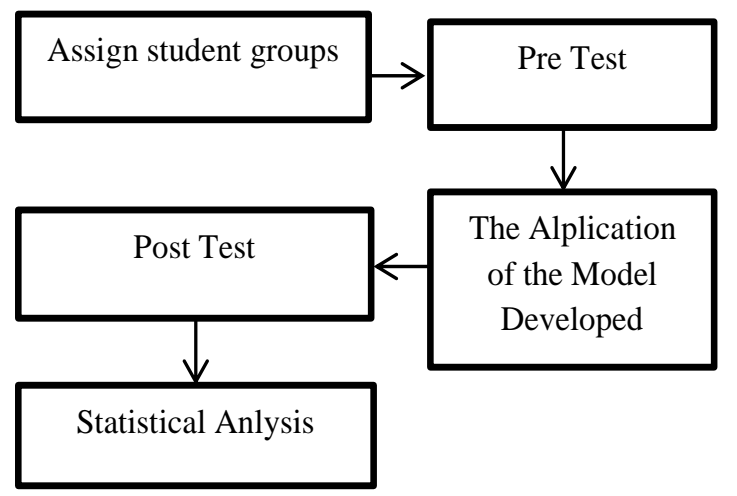

Figure 3. Steps Implementation the Effectiveness Test

The six steps of the pre-experimental test are carried out sequentially. The effectiveness test was carried out in Medan for students in the Physical Health and Recreational Education Study Program which spreaded across in 3 Universities. The respondents involved were 60 students. The participants were divided into 2 groups, 30 students for the control group and 30 students for the experimental group. The process of trial was carried out for 6 meetings, the number of these meetings was determined according to the tennis table subject curriculumin the Health Physical and Recreation Education Study Program.

\section{9) Final Product Revision}

After the potential and problems are shown factually and up to date, then a variety of information needs to be collected to be used as material for planning a certain products which are expected to solve the problem. 
10) Dissemination and Implementation

All of the development stages described above is carried out according to the order. But, in this study due to the limited cost and time, then the tenth stage cannot be carried out by the researcher.

Development Steps:

1. Preliminary Research as identification and needs analysis

2. Development Planning Model for learning models developments, researcher collaborate Forum Groups Discussion.

3. Validation, Evaluation and Model Revision, this model trial phase is aimed to determine whether the developed model is feasible or not.

4. Implementation of its model steps, Trial Design, Phase I Evaluation, Phase I trial (small scale), First product revision, Second Phase Evaluation.

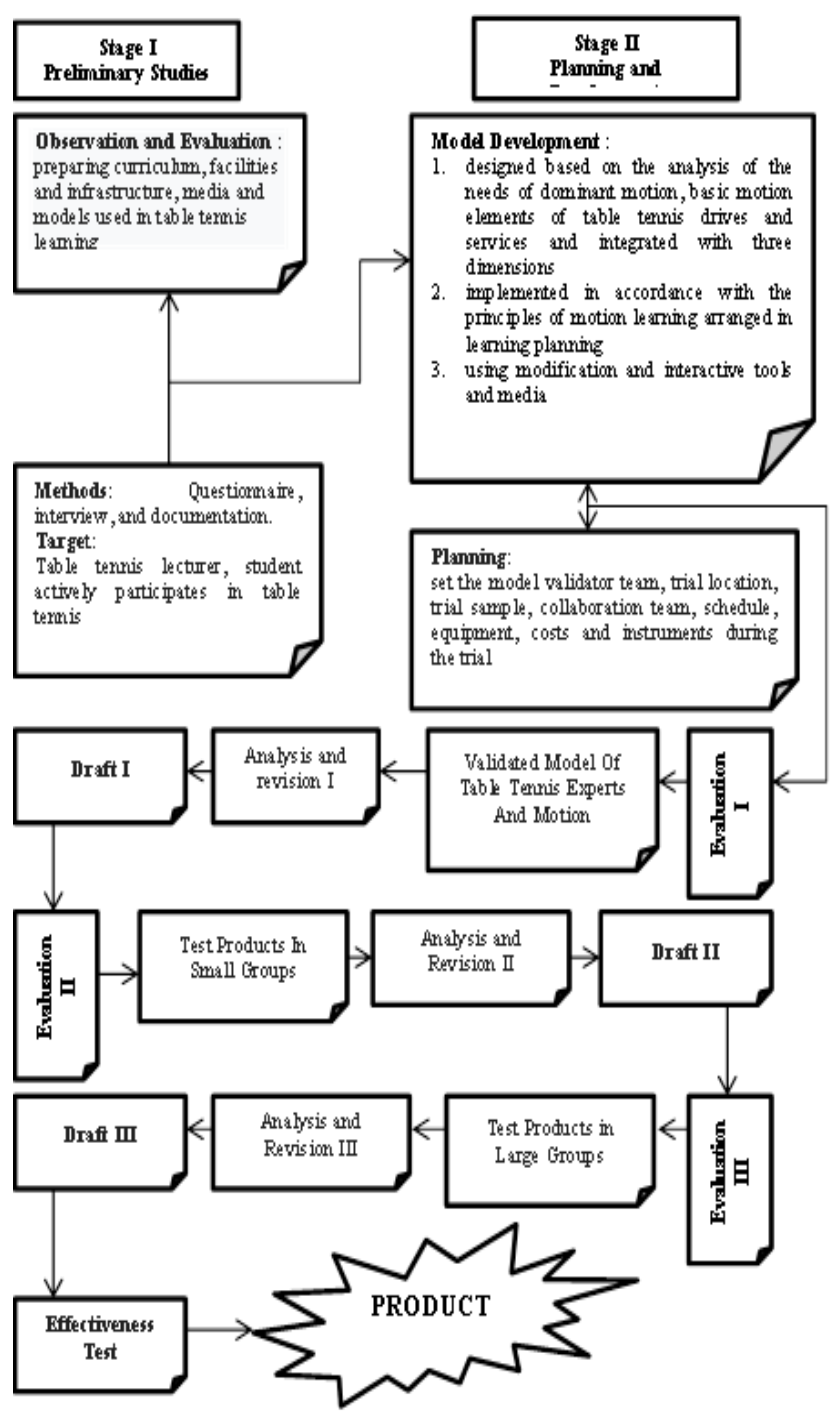

Figure 4. Design of Development Model

\section{RESUlts AND FINDINGS}

Information obtained through the preliminary study, all lecturers stated that the basic learning process of table tennis drive needs a better learning model which can create more active learning atmosphere, high motion activities, interesting and pleasing to students. $100 \%$ of students stated that they agreed that the basic learning techniques for table tennis drive were carried out in an interactive, fun and fast learning atmosphere. Based on this preliminary study, the development is resulted 40 designs of table tennis drive basic technique three-dimensional based learning model learning models.

Then expert judgments were carried out to get expert cosideration about the table tennis drive basic technique three-dimensional based learning model has validity. Based on the validation and evaluation from the expert judgment results, from 40table tennis drive basic technique models proposed, there were only 25 models to be continued to the field trial. As materials improvement and revision to the appropriate model, it is presented as follows;

a) Make the names for each model

b) Describe the equipments for each model

c) Improve image design for each model

d) Need to change the arrangement / sequence of the model

e) Grouping the models

f) Make a caption of each model

g) The goal is not appropriate

h) Implementation steps on some models are not appropriate

The results of the small-scale trial of table tennis drive basic technique three-dimensional based learning model which applied to novice students got $83.3 \%$ as a whole or very good. From the percentage, only 25 model sare feasible to be continued to a large group scale trials. The improvement or advice given by experts is as follows:

1) The expert advises to repair and changeall the various tools used as media related to the shape, position, size, and numbers.

2) The expert suggests for improve the learning process related to student grouping, pauses, giving examples at the beginning of learning process, warming up, reinforcement and motivation according to the students needs and class conditions.

3) The expert suggests for add the repetition movements of each model onimproving models.

Large-scale scale trials were carried out after small group scale trials and improvements have been made. Then, there were 25 drive basic technique three-dimension based learning models appropriate and ready to test on a large group scale. As explained before, the target of a large-scale scale trial were 90students which spreaded accross in Universitas Negeri Medan, Sekolah Tinggi Olahraga Kesehatan Binaguna Medan dan Universitas Pembangunan Masyarakat Indonesia Medan. The research was carried out for 1 semester (February upto May 2018). This large group scale trial was carried out in accordance with the learning planning program that had been designed previuosly. The results of a large-scale group trial on the table tennis drive three-dimensional based learning model as wholegot $86.9 \%$ with very good criteria. So, it can be concluded that the results of a large group scale trial, three-dimensional table tennis drive basic techniquethree-dimension based learning model is appropriate to be used as drive technique learning model for novice. Then, the observation results of large-scale trials were discussed with the experts to get suggestions and improvements for a good model. The following are suggestions and improvements that have been made by experts.

1) Various equipments used as media for learning aids were improved for its shape, position, size, and numbers

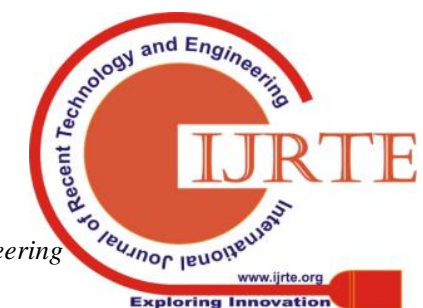


2) When the learning process, grouping students needs to be improved, pauses, giving examples at the beginning of learning, warming up, strengthening and motivating also need to be improved according to the needs and the conditions of the students.

3) Movements repetitions of each model needs to be added.

In this section, the effectiveness test of drive basic technique three-dimensional based learning model is carried out by using a different mean test (average) which is then analyzed by using the t-test (paired t-test), in the calculation of paired t-test (t-test) based on the data value of the pre-test For the results of the t-test calculation analysis, it can be seen in the following table.

Table 1. The results of the analysis of the average paired sample (forehand drive)

\begin{tabular}{|c|c|c|c|c|c|}
\hline \multicolumn{2}{|c|}{ Forehand Drive } & Mean & $\mathbf{T}$ & Df & $\begin{array}{c}\text { Sig } \\
\text { (2-tailed) }\end{array}$ \\
\hline \multirow{2}{*}{$\begin{array}{l}\text { Experimental } \\
\text { Group }\end{array}$} & Post-test & \multirow{2}{*}{-5.800} & \multirow{2}{*}{-34.353} & \multirow{2}{*}{29} & \multirow{2}{*}{0.00} \\
\hline & Pre-test & & & & \\
\hline \multirow{2}{*}{$\begin{array}{l}\text { Control } \\
\text { Group }\end{array}$} & Post-test & \multirow{2}{*}{-4.967} & \multirow{2}{*}{-21.376} & \multirow{2}{*}{29} & \multirow{2}{*}{0.00} \\
\hline & Pre-test & & & & \\
\hline
\end{tabular}

Table 1 shows the experimental group obtained a mean of $-5,800$ with a sig (2-tailed) value of $0.00<0.05$, which means that there is a significant difference between the results of the three-Dimensional table tennis forehand drive basic technique. The control group obtained a mean of $-4,967$ with a value of sig (2-tailed) $0.00<0.05$, which means that there were significant differences between the results of the pre-test and post-test oftennis table forehand drive basic techniques with conventional models.

Table 2. The results of the analysis are different from the average sample pair (backhand drive)

\begin{tabular}{|c|c|c|c|c|c|}
\hline \multicolumn{2}{|c|}{ Backhand Drive } & Mean & $\mathbf{T}$ & Df & $\begin{array}{c}\text { Sig } \\
\text { (2-tailed) } \\
\end{array}$ \\
\hline \multirow{2}{*}{$\begin{array}{l}\text { Experimental } \\
\text { group }\end{array}$} & Post-test & \multirow[t]{2}{*}{-5.933} & \multirow[t]{2}{*}{-27.717} & \multirow[t]{2}{*}{29} & \multirow[t]{2}{*}{0.00} \\
\hline & Pre-test & & & & \\
\hline $\begin{array}{l}\text { Control } \\
\text { group }\end{array}$ & $\begin{array}{c}\text { Post-test } \\
\text { Pre-test }\end{array}$ & -4.200 & -24.876 & 29 & 0.00 \\
\hline
\end{tabular}

Table 2 shows that the experimental group obtained a mean of $-5,933$ with a sig (2-tailed) value of $0.00<0.05$, which means that there is a significant difference between the results of the pre-test and post-test of table tennis forehand drive basic techniques learning with a three-dimensional model. The control group obtained a mean of -4.200 with a value of sig (2-tailed) $0.00<0.05$, which means that there are significant differences between the results of the pre-test and post-test of table tennis forehand basic technique with conventional models.

\section{Different test between samples (Independent samples tests) forehand drive and backhand drive}

The simultaneous different test between learning groups is to understand the differences in the influence of the two groups in improving the basic forehand drive technique before and after the experiment is given. The analysis technique used is and post-test of the experimental group and the control group.

by calculation of IBM SPSS 21.0 for Windows. The results can be seen in the following table.

Table 3. Results of analysis of independent samples test

\begin{tabular}{llcllc}
\hline & & Df & $\begin{array}{l}\text { Mean } \\
\text { Difference }\end{array}$ & F & Sig \\
\hline $\begin{array}{l}\text { Equal } \\
\text { variances } \\
\text { assumed }\end{array}$ & $\begin{array}{l}\text { Forehand } \\
\text { drive }\end{array}$ & 58 & 0.867 & 2.755 & 0.011 \\
\cline { 2 - 6 } & $\begin{array}{l}\text { Backhand } \\
\text { drive }\end{array}$ & 58 & 1.433 & 0.47 & 0.00 \\
\hline
\end{tabular}

Table 3. shows that the acquisition of significance value (2-tailed) is 0.01 , then $0.01<0.05$ which means that there are differences between the influence of drive basic technique three-dimension learning model with the conventional models in improving table tennis drive forehand basic technique skills of the students. Then, on the backhand drive, the acquisition of significance value (2-tailed) is 0.01 , then $0.00<0.05$ which means that there are differences in the influence of drive basic technique three-dimension learning model with conventional model exercises in improving tennis table drive backhand basic technique skills of the students. Based on the acquisition of the sig (2-tailed) value and the results of independent samples test analysis, between the two experimental groups and the control group both had significant values. This shows that students who study table tennis with drive basic tecnique three-dimension based learning model and students who study table tennis with conventional models can both make a positive contribution in improving basic skills of table tennis drive for novice. But, when it is seen from the average value achievement, the experimental group was higher than the average value of the control group. Thus, the final conclusion of this research is that the experimental group is better than the control group when comparedto the achievement of the average value obtained.

\section{CONCLUSIONS}

The development of table tennis-based learning methods based on play methods was carried out by researchers to help students with basic technical skills not particularly good for basic forehand drive techniques, backhand drive and table tennis services

\section{ACKNOWLEDGMENT}

The researchers would like to express special thanks to Physical Health and Recreation Education Study Program, Faculty of Sport Sciences, Universitas negeri Medan.

Ristek Dikti support and finance Research Doctoral Dissertation. Decree of Strengthening Research and Development Number 3 / E / KPT / 2018.

\section{REFERENCES}

1.Ma Y, He J, Yu Q. Modeling on social popularity and achievement: A case study on table tennis. Physica A: Statistical Mechanics and its Applications. 2019;524:235-45.

2. Thorburn M. John Dewey, subject purposes and schools of tomorrow: A centennial reappraisal of the educational contribution of physical education. Learning, Culture and Social Interaction. 2018;19:22-8. 
3. Black N, Johnston DW, Propper C, Shields MA. The effect of school sports facilities on physical activity, health and socioeconomic status in adulthood. Soc Sci Med. 2019;220:120-8

4. Chao Wang. Study on the Reform of Table Tennis Teaching Content and Methods in University. 5th International Conference on Social Science, Education and Humanities Research. 2016:4.

5. Jenkinson K, Benson A. Physical education, sport education and physical activity policies: Teacher knowledge and implementation in their Victorian state secondary school. European Physical Education Review. 2010;15(3):365-88.

6. Kim D, Ko YJ. The impact of virtual reality (VR) technology on sport spectators' flow experience and satisfaction. Computers in Human Behavior. 2019;93:346-56.

7. Shahbazi M, Menard P, Sohn G, Théau J. Unmanned aerial image dataset: ready for 3D reconstruction. Data in Brief. 2019:103962.

8. Kim M. Digital product presentation, information processing, need for cognition and behavioral intent in digital commerce. Journal of Retailing and Consumer Services. 2018.

9. Smith T. Adapting Table Tennis Instruction: Including Students With Disabilities In Physical Education 2008.

10. van Rensburg ESJ. Educators: Are you adequately supporting nursing students during mental health placements? International Journal of Africa Nursing Sciences. 2019;10:43-8

11. Shamkhalichenar H, Choi JW, Tiersch TR. Three-dimensional printing can provide customizable probes for sensing and monitoring in cryobiology applications. Cryobiology. 2019;88:64-9.

12. Erickson GB. Optimizing Visual Performance for Sport. Advances in Ophthalmology and Optometry. 2018;3(1):1-19.

13. Boby Helmi. Penerapan Variasi Pembelajaran Untuk Meningkatkan Hasil Belajar Pukulan Forehand Drive Permainan Tenis Meja Pada Siswa Kelas VIII Madrasah Tsanawiyah Al Abraar Perusahaan Terbatas Perkebunan Nusantara Ii Tandem Hilir I Tahun Ajaran 2015/2016. 2015.

14. de Kock A, Sleegers P, Voeten MJM. New learning and choices of secondary school teachers when arranging learning environments. Teaching and Teacher Education. 2005;21(7):799-816.

15. McNeill J, Howard SJ, Vella SA, Santos R, Cliff DP. Physical activity and modified organized sport among preschool children: Associations with cognitive and psychosocial health. Mental Health and Physical Activity. 2018;15:45-52.

16. Pummell EKL, Lavallee D. Preparing UK tennis academy players for the junior-to-senior transition: Development, implementation, and evaluation of an intervention program. Psychology of Sport and Exercise. 2019;40:156-64.

17. Mosoi AA. Skills and Motivation of Junior Tennis Players. Procedia Social and Behavioral Sciences. 2013;78:215-9.

18. Zetou E, Vernadakis N, Derri V, Bebetsos E, Filippou F. The Effect of Game for Understanding on Backhand Tennis Skill Learning and Self-efficacy Improvement in Elementary Students. Procedia - Social and Behavioral Sciences. 2014;152:765-71.

19. M. D. Gall WRB. Educational Research: An Introduction, 8th Edition. America: Pearson; 2007.

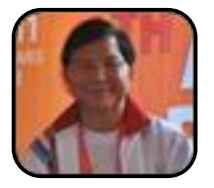

James Tangkudung,Professor of Physical Education, Postgraduate Program, Jakarta State University, Indonesia. My area of interest is e-learning and education.

Email: james24061952@gmail.com

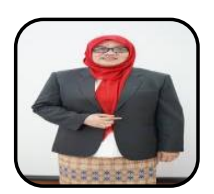

Nofimarlina Siregar, Lecture of Physical Education, Postgraduate Program, Jakarta State University, Indonesia Email: nofisiregar_fik96@yahoo.com

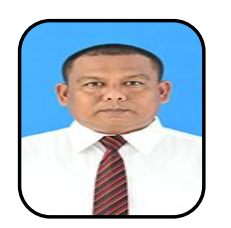

\section{AUTHORS PROFILE}

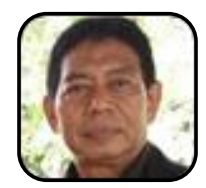

Samsuddin Siregar, Physical Education, Universitas Negeri Jakarta, Indonesia. Health and Recreation Physical Education, Universitas Negeri Medan, North Sumatera, Indonesia. My area of interest is e-learning and education. E-mail: sambatusundung@gmail.com

Firmasnyah Dlis, Professor of Physical Education, Postgraduate Program, Jakarta State University, Indonesia. My area of interest is e-learning and education. Email: firmansyahdlis.unj@gmail.com

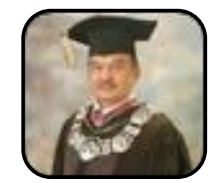

Achmad Sofyan Hanif,Professor of Physical Education, Postgraduate Program, Jakarta State University, Indonesia. My area of interest is e-learning and education. Email: sofyan_dean@yahoo.com 